\title{
EFISIENSI DAN DAYA SAING FREE FLOW OF SKILLED LABOUR DALAM PERSPEKTIF ECONOMIC ANALYSIS OF LAW: TELAAH PERATURAN PRESIDEN NOMOR 20 TAHUN 2018
}

(Economic Analysis of Law Perspective of Efficiency, Sovereignty, and Competitiveness of Free Flow of Skilled Labour: Analysis of the President Order Number 20 Year 2018)

\author{
Fajar Sugianto; Syofyan Hadi \\ Universitas 17 Agustus 1945 Surabaya \\ Jl. Semolowaru No.45, Sukolilo, Surabaya \\ Email: fajarsugianto@untag-sby.ac.id; syofyan@untag-sby.ac.id
}

Naskah diterima: 18 Agustus 2018; revisi: 31 Oktober 2018; disetujui: 5 November 2018

\begin{abstract}
Abstrak
Indonesia telah melakukan upaya-upaya mempersiapkan kebijakan serta mewujudkan regulasi khususnya tentang Tenaga Kerja Asing (TKA).Tujuan utama dari upaya-upaya ini selain turut serta dalam arus bebas tenaga kerja terampil, juga menjamin hak-hak warga Negara agar tetap mendapatkan pekerjaan dan kelayakan kehidupan. Indonesia juga berkewajiban memfasilitasi pergerakan tenaga kerja terampil. Terkait hal tersebut, pemberlakuan Perpres Nomor 20 Tahun 2018 tentang Penggunaan Tenaga Kerja Asing perlu ditelaah sejauh mana efisiensi pemberlakuan dan ketepatan substansi pengaturannya? Metode penelitian yang digunakan ialah Economic Analysis of Law sebagai analisis hukum dengan menggunakan bantuan ilmu ekonomi, dalam hal ini konsep efisiensi. Hasil penelitian menunjukkan masih terdapat banyak pengaturan yang inefisien dalam Peraturan Presiden ini seperti belum menekankan kepada daya saing, pencegahan kegagalan alih teknologi dan keahlian, belum mempromosikan kepentingan publik serta belum mampu mewajibkan informasi asimetris karena tidak melibatkan Tenaga Kerja Indonesia untuk memastikan kebutuhan riil penggunaan Tenaga Kerja Asing. Namun Peraturan Presiden ini sudah cukup efisien dalam hal pemangkasan birokrasi. Ke depannya, perlu dikembalikan lagi hakikat efisiensi baik dalam aspek birokrasi maupun ketepatan sasaran penggunaan TKA berdasarkan perbedaan keterampilan dan keahlian.
\end{abstract}

Kata kunci: Tenaga Kerja Asing, Daya Saing, Free Flow of Skilled Labour, Economic Analysis of Law

\begin{abstract}
Indonesia has performed special effort in order to prepare policy and regulation to compete in the free flow of skilled labour of ASEAN Economic Community. The main objective of this action is not only to participate in the free flow of skilled labour but also to guarantee the fundamental right of the citizens to have work and decent life. Indonesia is also obliged to facilitate the free flow of skilled labours. In that context, there is need to analyze the effectiveness of the Presidential Regulation Number 20 Year 2018 on the use of foreign workers in terms of its implementation and regulation. This paper uses Economic Analysis of Law method which uses economic theory, in this context, efficiency concept, to analyze the object. The research concludes that there are still many inefficient provisions in this presidential regulation such as: there's no stressing on competition, no anticipation provision for failed transfer of technology and skill, no enough promotion on public interest, and no obligation of providing asymetrical information because it doesn't involve Indonesian Workers to determine the need of Foreign Workers. However, this Presidential Decree is quite efficient in terms of debirocration. It is suggested that the Presiden Order need to expand the meaning of efficiency both in terms of birocration and the use of foreign workers based on labor, skill and expertise.
\end{abstract}

Keywords: Foreign Labor, Competitiveness, Free Flow of Skilled Labor, Economic Analysis of Law 


\section{A. Pendahuluan}

Sejak menghadapi arus bebas tenaga kerja terampil (free flow of skilled labour) dari tahun 2008 hingga 2015 sebagaimana tertuang dalam ASEAN Economic Community (AEC 2015), Indonesia telah melakukan upaya-upaya khususnya dalam hal mempersiapkan kebijakan serta regulasi khususnya terkait Tenaga Kerja Asing (TKA). Selain membentuk Pasar Tunggal Berbasis Produksi (Single Market Production Base), kebijakan ini bertujuan juga menjamin hak-hak warga Negara agar tetap mendapatkan pekerjaan dan kelayakan kehidupan seperti diamanatkan dalam Pasal 27 ayat (2) dan Pasal 28D ayat (2) Undang-Undang Dasar Negara Republik Indonesia Tahun 1945. Untuk mewujudkan amanat ini maka secara prinsip setiap warga negara, dalam hal ini Tenaga Kerja Indonesia (TKI), berhak untuk bekerja (right to work) dan hak-hak dalam pekerjaan (rights at work).

Hal tersebut memiliki akibat hukum kepada negara untuk melindungi setiap warga negaranya agar mendapatkan penghasilan melalui standar penghidupan yang baik sehingga mampu memenuhi kehidupannya secara wajar atas dasar harkat dan martabat kemanusiaan. ${ }^{1}$ Kewajiban negara tersebut juga perlu memperhatikan wujud nyata globalisasi ekonomi dan liberalisasi perdagangan dunia yang telah membentuk liberalisasi pasar yang terbuka dan bebas. Terbukanya pasar bebas dan terbuka ini merupakan grand design yang sulit dibendung sehingga tidak mungkin dapat dihindari terutama karena kuatnya pengaruh negara-negara maju (pro-globalisasi) yang secara ekonomi dan politik lebih kuat dan matang dibandingan negara-negara berkembang seperti Indonesia.

Fenomena globalisasi secara umum bertujuan untuk mengintegrasikan aspekaspek kehidupan dari seluruh negara-negara di dunia. Dengan demikian secara sempit, dapat dimaknai bahwa globalisasi memengaruhi aspek kehidupan setiap warga negara dan secara luas berdampak pada kedaulatan negara karena globalisasi dianggap memudarkan eksistensi negara itu sendiri. Menanggapi hal tersebut, Waters menjelaskan salah satu dari 4 (empat) alasan tentang posisi negara yang diperlemah akibat adanya globalisasi yakni dikarenakan meningkatnya hubungan ekonomi dan budaya yang mereduksi kekuatan negara sehingga kontrol pemerintah dalam kebijakan internal tidak efektif. $^{2}$

Di sisi lain Campbell melihat globalisasi ekonomi sebagai ancaman bagi ekspor negara, tingkat manipulasi harga yang tinggi, dan terjadi dislokasi harga. Namun ia berpendapat bahwa globalisasi jelas merusak hubungan antarbangsa karena sifatnya yang borderless. Campbell menyarankan bahwa negara seharusnya memiliki pertahanan untuk menghadang arus globalisasi demi terciptanya unsur keamanan ${ }^{3}$.

Berbagai bentuk fenomena globalisasi seharusnya tidak berpengaruh terhadap negara yang berdaulat karena hakikat negara terletak pada kedaulatannya. Kedaulatan merupakan esensi dari negara, karena tanpa kedaulatan 
maka tidak ada negara. ${ }^{4}$ Menurut teori monistis, bahwa kekuasaan negara merupakan keuasaan tertinggi dan tidak terbatas, yang memaksakan perintah-perintahnya dengan tidak mengindahkan perintah-perintah lainnya. ${ }^{5}$ Lebih lanjut lagi, F. Isjwara menambahkan negara yang memiliki kekuasaan tertinggi itu menghendaki penataan mutlak dari semua warga negara. Kekuasaan negara yang mutlak itu terjelma dalam bidang peraturan perundangundangan, di mana negara merupakan pembentuk undang-undang yang tertinggi ${ }^{6}$.

Dalam hal terjadinya arus bebas tenaga kerja terampil sebagaimana tertuang dalam AEC 2015 guna menciptakan pasar tunggal berbasis produksi dengan cara meningkatkan dinamika dan pasar kompetitif, semua negara anggota ASEAN berkomitmen untuk memfasilitasi penerbitan visa dan ijin kerja untuk tenaga profesional dan terampil yang terlibat dalam perdangan lintas batas dan kegiatan terkait investasi. Dalam ASEAN Economic Community Scorecard: Performance and Perception disebutkan bahwa:

In allowing for managed mobility or facilitated entry for the movement of natural persons engaged in trade of goods, services, and investments, according to the prevailing regulations of the receiving country, ASEAN is working to: facilitate the issuance of visas and employment passes for ASEAN professionals and skilled labour who are engaged in cross-border trade and investment related activities. ${ }^{7}$ (Terjemahan bebas, dalam memungkinkan mobilitas yang dikelola atau difasilitasi masuknya pergerakan orang perorangan yang terlibat dalam perdangan barang, jasa, dan investasi sesuai dengan peraturan yang berlaku di negara penerima, ASEAN bekerja untuk memfasilitasi penerbitan visa dan ijin kerja untuk tenaga profesional dan terampil yang terlibat dalam perdangan lintas batas dan kegiatan terkait investasi).

ASEAN sendiri mendeklarasikan telah berhasil mengintegrasikan ekonomi regional ASEAN sejak pembentukan AEC (2008-2015) dengan menawarkan peluang dalam bentuk pasar sebesar US\$ 2,6 Triliun dan lebih dari 622 juta orang. Hasilnya, pada tahun 2014 AEC secara kolektif menjadi ekonomi terbesar ketiga di Asia dan ketujuh terbesar di dunia. ${ }^{8}$ Dari sudut pandang ini, negara-negara anggota ASEAN memiliki visi AEC 2025 yang bertumpu pada sikap inovatif dan dinamis; peningkatan konektivitas dan kerjasama sektoral; dan komunitas yang lebih tangguh, inklusif, dan berorientasi pada masyarakat yang terintegrasi dengan ekonomi global.

Dalam hal ketenagakerjaan, ASEAN menganggap telah berhasil memfasilitasi pergerakan tenaga kerja terampil. Maka kini agenda terbesar yang ada adalah untuk mewujudkan karakteristik ke-lima, yakni Facilitating Movement of Skilled Labour and Business Visitors melalui salah satu langkah strategis dengan cara mengurangi dokumentasi

\footnotetext{
Soehino, Ilmu Negara, (Yogyakarta: Liberty, 2013), hlm. 88.

5 Hufron dan Syofyan Hadi, Ilmu Negara Kontemporer; Telaah Teoritis Asal Mula, Tujuan dan Fungsi Negara, Negara Hukum dan Negara Demokrasi (Yogyakarta: Laksbang Grafika, 2016), hlm. 99.

$6 \quad$ F. Ijswara, Pengantar Ilmu Politik (Jakarta: Binacipta, 1992), hlm. 108.

7 Sanchita Basu Das, ASEAN Economic Community Scorecard: Performance and Perception (Singapore: ISEAS, 2013), hlm. 114. $\quad$ Van Eechoud, The defendant usually resides in the same state in which it carries out its activities and is often the only state with jurisdiction di dalam Lydia Lundstedt, Territoriality in intellectual property law, Stockholm University (Stockholm:Sweden by Holmbergs,2003), hlm. 33. 
perijinan, jika tidak terstandarisasi, untuk memfasilitasi pergerakan lintas batas sementara.

Meresponi perkembangan ini, Pemerintah telah menetapkan Peraturan Presiden No. 20 Tahun 2018 tentang Penggunaan Tenaga Kerja Asing (Perpres TKA). Meski demikian, pemerintah harus secara bijak mengambil sikap tidak saja mengikuti globalisasi ekonomi dalam ruang lingkup ASEAN tetapi juga memperhatikan kesiapan kebijakan dan regulasi dengan cara memperhatikan efisiensi peraturan perundangundangan di bidang ketenagakerjaan dengan tetap berporos pada hak konstitusional warga Negara melalui regulasi. Efisien dalam konteks berdaya guna, tepat sasaran sehingga mencapai keberhasilan maksimum dalam suatu tindakan dalam keadaan kompetitif. Pembentukan Peraturan Presiden No. 20 Tahun 2018 tentang Penggunaan Tenaga Kerja Asing (Perpres TKA) karena itu menarik untuk ditelaah lebih jauh efisiensi pemberlakuannya dan ketepatan substansi pengaturannya

\section{B. Metode Penelitian}

Berdasarkan uraian tersebut tulisan ini mengangkat isu hukum tentang efisiensi, kedaulatan negara dan daya saing Free Flow of Skilled Labour dalam perspektif Economic Analysis of Law (EAL). EAL merupakan analisis hukum dengan menggunakan konsep-konsep, alasan serta pertimbangan ekonomi dalam menjawab permasalahan hukum. ${ }^{9}$ Dengan tetap mengarahkan analisis hukum, bantuan ilmu ekonomi menjadi salah satu pendekatan guna menjawab permasalahan hukum secara lebih luas, khususnya pada aspek tertentu yang tidak dapat dijelaskan lebih komprehensif oleh ilmu hukum.

EAL dapat dijadikan suatu metode untuk menjawab permasalahan hukum dengan mengutarakan definisi berbeda dan asumsi yang berbeda, dalam hal ini dari sudut pandang ekonomi, untuk mendapatkan gambaran tentang kepuasan (satisfaction) dan peningkatan kebahagiaan (maximization of happiness) yang erat kaitannya dengan keadilan hukum. Untuk melakukannya maka hukum dijadikan economic tools guna mencapai maximization of happiness. ${ }^{10}$

EAL sebagai suatu metode selain berisikan analisis ekonomi terhadap permasalahan hukum, juga harus disusun dengan pertimbangan ekonomi dengan tidak menghilangkan keadilan, sehingga keadilan selalu menjadi economic standard terhadap pemberlakukan hukum (the economic conception of justice). ${ }^{11}$ Dengan demikian, EAL dalam tulisan ini berguna sebagai metode yang menilai sampai sejauh mana dampak pemberlakukan Perpres TKA terhadap masyarakat luas, sehingga lebih mudah diketahui reaksi masyarakat dan kemafaatan yang mampu diberikan oleh Perpres TKA tersebut. Dengan menggunakan telaah EAL yang dikonstruksikan melalui alasan-alasan ekonomi untuk menjelaskan akibat hukum, mengevaluasi dan mengestimasi sifat dasar, kemampuan dan kualitas Perpres TKA yang efisien sehingga dapat diprediksi model pengaturan Perpres TKA yang patut diberlakukan.

\footnotetext{
Fajar Sugianto, Economic Analysis of Law, Seri Analisis Ke-ekonomian tentang Hukum (Jakarta: Kencana Prenada Media Group, 2013), hlm 22.

10 Bushan J. Komadar, Journal: The Raise and Fall of a Major Financial Instrument, (University of Westminster, 2007), hlm. 1.

11 Richard A. Posner, Economic Analysis of Law, Edisi 7 (New York: Aspen Publishers, 2007), hlm. 15.
} 


\section{Pembahasan}

\section{Landasan Teori dan Uraian Konsep \\ a. Konsep Efisiensi}

Secara harafiah, konsep efisiensi selalu dikaitkan dengan pengertian penghematan yang terkait dengan penilaian ekonomis dari suatu barang dan/atau jasa. Efisien yang bersifat ekonomis berarti "tingkat yang dapat dicapai oleh produksi maksimal dengan pengorbanan minimal". Efisiensi suatu perusahaan diukur oleh keuntungan dan biaya, sebab produsen yang paling efektif adalah dia yang keuntungannya mencapai tingkat yang maksimal dan biayabiayanya merupakan suatu kombinasi yang tepat daripada faktor-faktor produksi, dapat diperkecil serendah-rendahnya"12. Efisiensi dapat diukur dari tingkat keberhasilan maksimum dalam suatu tindakan ekonomi dengan memperhatikan daya saing (produce and the allocation of goods). ${ }^{13} \mathrm{Di}$ sisi lain, Cooter dan Ulen menggarisbawahi bahwa suatu produk dapat dikatakan efisien dan melalui proses produksi yang efisien juga apabila mutu kapasitasnya atau kesanggupan, daya produksi, kemampuan untuk menghasilkan hasil yang diinginkan secara tetap, memiliki daya guna, dan tepat sasaran. ${ }^{14}$

Lebih lanjut lagi, Vilfredo Pareto mengemukakan konsep allocative efficiencyyang hingga sekarang dikenal dengan Pareto Efficiency yang pada dasanya menitikberatkan pada pencapaian kepuasan seseorang. Menurutnya, suatu peristiwa dapat menghasilkan nilai efisiensi apabila dapat membuat para pihak di dalamnya menjadi lebih baik, atau paling tidak, tidak ada satu pihak yang menjadi sengsara. ${ }^{15}$ Lanjutnya, allocative efficency terbangun dari 2 (dua) konsep, yaitu superiority dan optimality. Pareto superiority adalah suatu keadaan ekonomi yang pertukarannya dapat dilakukan untuk membawa keuntungan kepada seseorang dan tidak merugikan seorangpun. Ketika pertukaran semacam ini tidak dapat dilaksanakan, maka situasinya menjadi pareto optimality yaitu suatu keadaan ekonomi yang tidak membuat seorang pun menjadi lebih baik tanpa merugikan atau menjadikan seseorang lebih buruk.

Konsep efisiensi lainnya yang umum diadopsi dalam Hukum dan Ekonomi ialah KaldorHicks Efficiency. Menurut mereka, "efficiency is a situation in which all possible wealthmaximizing changes have occurred. ${ }^{16}$ Sehingga dapat dipahami bahwa suatu keadaan dikatakan efisien apabila dihasilkan dari suatu pertukaran alokasi sumber daya yang menguntungkan si pemenangnya. Dikatakan pemenang apabila ia lebih mendapatkan keuntungan dengan cara memperoleh manfaat dari pertukaran tersebut, tidak dengan cara mengeksploitasi atau merugikan pihak lainnya.

Ronald $\mathrm{H}$. Coase melihat efisiensi dapat diukur dari besarnya biaya transaksi (transaction cost) sebagai eksternalitas. Biaya transaksi adalah segala biaya yang dikeluarkan dalam melakukan pertukaran. ${ }^{17}$ Dapat berupa hal-hal seperti biaya yang timbul dari pengkomunikasian

\footnotetext{
A. Abdurachman, Ensiklopedia Ekonomi Keuangan Perdagangan (Jakarta: Paradnya Paramita, 1980), hlm. 378. Svetozar Pejovich, Law, Informal Rules and Economic Performance (USA: EE, 2008), hlm. 9.

Robert Cooter dan Thomas Ulen, Law and Economics (London: Pearson Addison Wesley, 2008), hlm. 17. Bryan A. Garner, Black's Law Dictionary, $8^{\text {th }}$ edition (USA: Thompson West Group, 2004), hlm. 1147.

Ibid.

17 Ronald H. Coase, "The Problem of Social Cost", The Journal of Law and Economics, The University of Chicago Press (1960), hlm. 67.
} 
dan merupakan biaya yang menghambat pertukaran. Dari sini dapat dipahami bahwa pertukaran seharusnya berhasil ketika biaya transaksi adalah nol.

Pada saat suatu keadaan memiliki biaya transaksi tinggi, seharusnya peraturan perundang-undangan menekan biaya transaksi tersebut sehingga para pihak yang terlibat di dalamnya dapat melakukan pertukaran yang saling menguntungkan. Dalam hal efisiensi pengaturan penggunaan TKA, setidaktidaknya dapat diukur ketika biaya transaksi menjadi endogen terhadap sistem hukum yang ada, dalam pengertian, pengaturan TKA dapat menekan hambatan-hambatan dalam private bargaining yang berpotensi berbiaya tinggi, seperti biaya pencarian (search cost), biaya pertukaran (bargaining cost), dan biaya penegakkan (enforcement cost). Ketika Perpres TKA mampu melancarkan interaksi dan transaksi (bargaining) dengan cara pertukaran secara volunter, maka pengaturan tersebut efisien. Sebaliknya, jika dengan diberlakukannya Perpres TKA justru menciptakan celah (gap) dalam bentuk risiko dan keadaan tidak menentu maka dapat dipastikan keberlakuannya tidak efisien.

\section{b. Konsep Free flow of Skilled Labour}

AEC 2015 berisikan 4 (empat) karakteristik yakni: i) Single Market Production Base; ii) Competitive Economic Region; iii) Equitable Economic Region; dan iv) Linkages with Global Economy. Masing-masing karakteristik tersebut berisikan berbagai indikator, termasuk kebijakan tentang tenaga kerja. Pada karakteristik pertama, Single Market Production Base dicirikan dengan berbagai arus bebas, termasuk di dalamnya arus bebas tenaga kerja terampil (free flow of skilled labour) di wilayah Asia Tenggara, bukan tenaga kerja belum terampil. Hal ini memberikan kesempatan bagi setiap warga negara anggota ASEAN untuk turut menikmati keterbukaan lapangan kerja. Oleh karena yang menjadi objek arus bebas adalah tenaga kerja yang terampil, maka untuk menikmatinya TKI harus memiliki keahlian dan keterampilan yang memadai sesuai dengan profesinya masing-masing.

Tidak semua profesi masuk ke dalam kategori terampil yang diarusbebaskan. Hal ini sudah ditentukan di dalam ASEAN Qualification Reference Framework (AQRF) yang disahkan oleh para Menteri Ekonomi ASEAN di tahun 2014, para Menteri Pendidikan ASEAN juga di tahun 2014, dan para Menteri Ketenagakerjaan ASEAN pada tahun 2015. Selain AQRF, Mutual Recognition of Skills (MRS) yang diinisiasi oleh International Labor Organization khusus mengenai keterampilan teknis/vokasi juga menjadi tolak ukur profesi apa saja yang dapat dikategorisebagaitenaga kerja terampilsehingga dapat mengikuti arus bebas tersebut. Hasilnya, keduanya memberikan pengakuan bahwa profesi-profesi yang dapat diarusbebaskan ialah yang terlibat dalam bidang ilmu: teknik, keperawatan, arsitektur, survei tanah, medis, dokter gigi, akutansi, dan pariwisata. Dengan demikian, sangat jelas bahwa dalam hal arus bebas tenaga kerja terampil tidak berarti pergerakan bebas manusia (free movement of people) tetapi arus bebas tenaga kerja yang memiliki keterampilan di bidang-bidang yang telah ditentukan tersebut.

Menurut konsep daya saing dan konsep free flow of skilled labour, maka persaingan akan terjadi di 8 (delapan) bidang pekerjaan tersebut dengan memperhatikan kesanggupan, kemampuan dan kekuatan untuk saling bersaing antara profesional satu dengan yang lain dengan memacu keunggulan masing-masing 
baik secara komparatif maupun kompetitif. Keunggulan komparatif dapat ditinjau dengan cara saling membandingkan kualitas keterampilan di bidangnya masing-masing (sesama profesi) dengan profesi yang sama dari negara anggota ASEAN yang lain. Cara seperti ini akan menumbukan persaingan sehat yang pada akhirnya pasar akan memilih dan memakai tenaga kerja yang dirasa paling terampil dengan berbagai macam pertimbangannya, seperti upah, etos kerja, kesadaran, dedikasi, dan lain sebagainya. Keunggulan kompetitif dapat ditinjau dari pada kemampuan negara untuk memformulasikan strategi peningkatan keterampilan dan keahlian yang siap pakai sesuai dengan ketersediaan lapangan pekerjaan yang ada, seperti pendidikan lanjutan, etos kerja, dedikasi, dan hal lain yang menjadi nilai tambah di dalam keunggulan komperatif tenaga kerja itu sendiri.

Berdasarkan hal tersebut dapat diketahui bahwa suatu keunggulan walaupun bisa dibedakan menjadi keunggulan komperatif dan kompetitif, namun keduanya sangat berkaitan erat dan tidak dapat dipisahkan dalam hal daya saing arus bebas tenaga kerja terampil. Agar dapat mengikuti arus bebas tersebut, sebagai tenaga kerja profesional harus mampu meningkatkan keahlian dan keterampilannya di 8 (delapan) bidang tersebut agar dapat bersaing dengan tenaga kerja profesional dari negara anggota ASEAN yang lain. Begitupula dengan negara harus mampu meningkatkan kualitas tenga kerja profesionalnya serta menggunakan strategi yang efisien agar:

1) tenaga kerja profesional Indonesia dapat mengikuti arus bebas tenaga kerja terampil dengan cara menyiapkan kualitas tenaga kerja profesional Indonesia sesuai dengan jenis lapangan pekerjaan yang ada di negara anggota ASEAN; dan

2) tenaga kerja profesional Indonesia yang belum dapat mengikuti arus bebas tenaga kerja terampil dapat bertahan menghadapi kedatangan tenaga kerja profesional dari negara anggota ASEAN yang lain.

Agar daya saing ini dapat terjaga, negara berdaulat yang memiliki segala kekuasaan harus konsisten mengatur lalu lintas arus bebas tenaga kerja terampil yang masuk ke Indonesia dengan cara memfasilitasi pergerakan tenaga kerja terampil dan pengunjung bisnis (Facilitating Movement of Skilled Labour and Business Visitors) melalui salah satu langkah strategis dengan cara mengurangi dokumentasi perijinan, jika tidak terstandarisasi untuk memfasilitasi pergerakan lintas batas sementara hanya kepada tenaga kerja terampil, bukan terhadap tenaga kerja tidak terampil (unskilled labour).

\section{c. Teori Daya Saing}

Menurut Porter, daya saing adalah tingkat produktivitas yang diartikan sebagai output yang dihasilkan oleh suatu tenaga kerja. ${ }^{18}$ Pendapat ini menyatakan bahwa suatu negara memperoleh keunggulan daya saing jika perusahaan yang ada di negara tersebut kompetitif. Tambunan menambahkan bahwa daya saing merupakan keunggulan pembeda dari yang lain yang terdiri dari comparative advantage (faktor keunggulan

18 Michael Porter, "The Competitive Advantage of Nations" https://hbr.org/1990/03/the-competitive-advantageof-nations, Harvard Business Review (diakses 22 Mei 2018). 
komparatif) dan competitive advantage (faktor keunggulan kompetitif). ${ }^{19}$

Dalam hal tenaga kerja, keunggulan komperatif menekankan tentang cara untuk mencapai tujuan bersama dengan segala keunggulan yang dimiliki baik oleh tenga kerja yang satu terhadap tenaga kerja lainnya. Sedangkan keunggulan kompetitif menekankan tentang cara memanfaatkan keunggulan yang dimiliki tenaga kerja tersebut agar dapat mendapatkan tujuan bekerja dengan cara berkompetisi dengan tenaga kerja lainnya. Oleh karena yang menjadi objek kompetisi adalah lapangan pekerjaan yang saling diperebutkan oleh antar individu atau antara beberapa komunitas, maka persaingan dalam konteks ini memiliki fungsi sebagai alat untuk melakukan seleksi sosial dan untuk menghasilkan pembagian kerja yang tepat dan efektif.

Seleksi sosial dapat dilakukan ketika persaingan disadari oleh dasar pemikiran sehat sehingga pada akhirnya individu atau komunitas tertentu akan bertahan dan akan tetap tersedia lapangan pekerjaan baginya karena memiliki kualitas dan keterampilan yang lebih baik dibandingkan dengan tenaga kerja yang lain dengan biaya yang sama. Dalam menghasilkan pembagian kerja yang tepat dan efektif, dengan adanya persaingan kerja, kemampuan serta kualitas akan terlihat jelas sehingga segala bentuk kekurangan dan kelebihan tenaga kerja tersebut. Oleh karena itu, dengan adanya persaingan, pasar akan menentukan posisi dan kedudukan setiap tenaga kerja yang tepat sesuai dengan kemampuan dan keterampilannya sehingga kegiatan ekonomi dapat berjalan dengan efektif.

Penjelasan tersebut memberikan pemahaman bahwa ketersediaan lapangan pekerjaan di era kompetitif sekarang ini erat kaitannya dengan keterampilan. Survey 2015 menunjukan bahwa Indonesia masih memiliki rasio 8:2 antara tenaga kerja terampil (skilled worker) dengan yang tidak terampil (unskilled worker). Angka ini masih relatif lebih baik dibandingkan dengan negara-negara berkembang lainnya seperti Vietnam (7:3), Malaysia (3:7), dan Thailand (2:8). ${ }^{20}$

Dalam hal tingkat kesiapan keterampilan (skill preparedness) pada saat ini dan di masa yang akan datang, Indonesia masih berada di tingkat kesiapan pada saat ini 50:50 antara rendah dan tinggi, sementara dalam hal kesiapan di masa datang, Indonesia menduduki posisi di bawah rata-rata. ${ }^{21}$

\section{Economic Analysis of Law Terhadap Peraturan Presiden No. 20 Tahun 2018 tentang Penggunaan Tenaga Kerja Asing}

Banyak perbedaan pengelompokan keterampilan tenaga kerja oleh para pakar, dalam penulisan ini guna mendapatkan kejelasan terhadap arus bebas TKA berdasarkan AEC 2015 cukup dikelompokan menjadi 2 (dua), yakni TKA terampil (skilled) dan TKA berketerampilan rendah (low skilled).

\footnotetext{
Tulus Tambunan, Makalah: "Pengusaha KADIN Brebes Di Dalam Era Globalisasi: Tantangan dan Ancaman" (Makalah Diskusi dalam Temu Usaha Kadin Brebes 20 Desember 2004).

20 The Federation of Thai Industries, ASEAN Affairs Department of Foreign Affairs Ministry and the International Labour Organisation, 2015.

21 Gad Levanon et all, "Help Wanted: What Looming Labor Shortages Mean for Yor Business" (The Conference Board, Research Report R-1601-16RR, 2016).
} 
Dengan mengetahui kejelasan tentang arus bebas tenaga kerja terampil (free flow of skilled labour) yang tidak sama dengan pergerakan bebas manusia (free movement of people) maka terbuka keleluasaan perspektif tentang keberadaan tenaga kerja yang tidak terkategori berkerampilan rendah (low skilled labour). Ada yang berpendapat bahwa arus bebas tenaga kerja terampil masih dirasa tidak optimal karena setiap negara anggota ASEAN memiliki lembaga dan pengaturan hukum ketenagakerjaan yang berbeda-beda dan hingga saat ini belum tercapai unifikasi terhadapnya. Permasalahan lain disebabkan oleh belum adanya kesesuaian pendapat secara lebih luas mengenai pengakuan keterampilan dari dan antara negara anggota ASEAN. Dalam konteks daya saing, tujuannya ialah persaingan secara alami yang pada akhirnya terjadi seleksi sosial. Berdasarkan perkembangan seperti ini, liberalisasi pasar tenaga kerja akan menawarkan manfaat kepada tenaga kerja berketerampilan rendah, mengingat selain belum diatur pergerakannya tetapi juga jumlah kebutuhan keterampilan tersebut di Indonesia masih terbuka. Selain itu tenaga kerja daerah sebagian besar masih didominasi oleh pekerja berketerampilan rendah. ${ }^{22}$

Terdapat 2 (dua) alasan dasar untuk menguji ketepatan-sasaran suatu kebijakan yang terdapat dalam suatu regulasi, yakni, pertama alasan ekonomi, dengan mempertimbangkan tujuan seperti pencegahan monopoli, internalisasi eksternalitas, mendorong alih teknologi, kepentingan publik, dan informasi asimetris. Kedua, alasan hukum (sebagai alasan non ekonomi) dengan tetap memperhatikan tujuan seperti mencapai keadilan distributif, nilai-nilai komunitas, dan kesejahteraan individu. ${ }^{23}$ Dengan pemberlakuan Perpres TKA, kajian EAL terhadapnya dilakukan dengan mengutarakan alasan-asalan ekonomi dan hukum guna mendapatkan jawaban terhadap efisiensi kebijakan pemberlakuan Perpres TKA.

Dalam melakukan pengujian terhadap Perpres TKA, alasan ekonomi yang menjadi pertimbangan, yaitu: Pertama, Mencegah monopoli atau mengurangi dampaknya. Persaingan merupakan pusat ekonomi pasar. Teori umum mengasumsikan bahwa konsumen memiliki pilihan terhadap kualitas barang/jasa yang mereka beli. Oleh karena itu pasar hanya akan memilih hasil terbaik dari hasil persaingan ini. Praktek monopoli akan membatasi pasokan dan menjaga harga terlalu tinggi. Ketika pemerintah dengan terpaksa memelihara monopoli alami, maka langkah efektif yang dapat dilakukan ialah mencegah penyalahgunaan monopoli. Persaingan berdasarkan keterampilan dan keahlian merupakan pusat perhatian pengusaha. Para pengusaha dalam hal ini akan memilih kualitas tenaga kerja yang mereka pekerjakan. Oleh karenanya pengusaha akan hanya memilih tenaga kerja yang dianggapnya paling efisien sesuai dengan kebutuhan pekerjaannya berdasarkan rasionalitas yang ada. Efisien tidaknya tenaga kerja menurut alasan ini tidak berpengaruh kepada nasionalitas tenaga kerja itu sendiri melaintkan menitikberatkan kepada keterampilan dan keahlian yang dimiliki tenaga kerja tersebut agar dapat membawa keuntungan kepada pengusaha.

\footnotetext{
22 Gad Levanon et all, "Help Wanted: What Looming Labor Shortages Mean for Yor Business" (The Conference Board, Research Report R-1601-16RR, 2016).

23 David Kraybill dan Maureen Kilkenny, Economic Rationales for and Against Place-Based Policies (USA: Cornell University, 2002), hlm. 3-5.
} 
Arus bebas tenaga kerja terampil akan menjadi efisien jika hanya bertujuan untuk menghilangkan monopoli atau penyalahgunaan monopoli, contohnya dominasi tenaga kerja Malaysia terhadap TKI di sektorsektor tertentu. ${ }^{24} \mathrm{Hal}$ ini sesuai dengan asas kesempatan dan perlakuan yang sama tanpa diskriminasi sebagaimana ditentukan dalam ketentuan Pasal 5 jo. Pasal 6 Undang-Undang Republik Indonesia Nomor 13 Tahun 2013 tentang Ketenagakerjaan. Oleh karenanya, Perpres TKA jika ditelaah berdasar asas tersebut, TKA seharusnya baru mendapatkan pekerjaan di Indonesia hanya jika tidak ada lagi pilihan lain berdasarkan keterampilan dan keahlian yang diinginkan oleh pengusaha. Namun tidak diwajibkan kepada Pemberi Kerja TKA untuk mempublikasikan kebutuhan TKA yang belum dapat diduduki oleh TKI selain dengan cara mengajukan Rencana Penggunaan Tenaga Kerja Asing yang disahkan oleh Menteri.

Keharusan TKA yang bekerja di Indonesia menyertakan tenaga kerja pendamping berwarganegara Indonesia disertai dengan surat pernyataan penunjukan tenaga kerja pendamping menjadi efisien jika diatur pula tentang sanksi hukum terhadap pelanggaran pernyataan tersebut. Hal ini menunjukan adanya penjaminan terhadap proses alih teknologi dan alih keahlian, tidak saja terhadap tenaga kerja pendamping yang diharuskan mendapatkan pelatihan tetapi juga kepada TKA yang pada akhirnya mampu berbahasa Indonesia.

Dalam hal terjadi keunggulan komparatif sama dengan keunggulan kompetitif, artinya keterampilan dan keahlian TKA ternyata dimiliki oleh TKI namun TKA tersebut mendapatkan pekerjaan di Indonesia. Fenomena ini dapat dijelaskan oleh alasan ekonomi selanjutnya.

Kedua, menginternalisasi eksternalitas (dampak pihak ketiga). Dampak pihak ketiga dapat menjadi salah satu penyebab kegagalan pasar. Dalam hal TKA berketerampilan rendah mendapatkan pekerjaan di Indonesia sementara jumlah ketersediaan angka dan keterampilan TKI masih mencukupi, maka telah terjadi kegagalan pasar. Jika arus pergerakan TKA berketerampilan rendah tidak diatur, atau dibiarkan tidak diatur, maka pengusaha tidak akan menginternalisasi eksternalitas tersebut. Karena sangat jelas yang diberikan kemudahan dalam arus bebas tenaga kerja adalah yang memiliki keterampilan di 8 (delapan) bidang profesi dan warga negara anggota ASEAN. Dalam hal lapangan pekerjaan ternyata didominasi oleh TKA low skilled di luar wilayah ASEAN, maka Perpres TKA seharusnya mengintervensi dengan pengertian berusaha untuk mencegah atau memperbaiki masalah ini berdasarkan kondisi pasar, yakni AEC, dan risiko yang ditimbulkan dari pihak ketiga. Sehingga pembenahan sistem yang memperketat pengawasan dan penegakkan hukum ialah sistem penggunaan TKA berketerampilan rendah dari negara non ASEAN yang masuk ke Indonesia.

Dengan mendasarkan pada tujuan ini, kriteria TKA menurut Pasal 1 angka 1 Perpres TKA belum mampu menginternalisasi eksternalitas karena tidak membedakan pergerakan TKA ASEAN maupun Non ASEAN, terlebih lagi tidak menarik batas jelas antara TKA terampil dan TKA berketerampilan rendah.

Selain itu pada sisi alih teknologi dan alih keahlian, Perpres TKA tidak menginternalisasi

24 Satrio Widianto, "Tenaga Kerja Asing Dari 5 Negara Masih Dominan",http://www.pikiran-rakyat.com/ ekonomi/2014/08/17/293351/tenaga-kerja-asing-dari-5-negara-masih-dominan, Pikiran Rakyat (diakses 25 Mei 2018) 
ekternalitas dalam hal tidak terjadinya alih teknologi dan alih keahlian sebagaimana ditentukan dalam Pasal 27 Perpres TKA tanpa menentukan sanksi jika proses alih ini tidak terjadi. Jika ini terjadi, dengan sendirinya kebutuhan penggunaanTKAtidakakanberkurang dan kehadiran tenaga kerja pendamping di setiap penggunaan TKA akan memperbesar jumlah eksternalitas. Di sisi lain, Perpres TKA memberikan kejelasan tentang pembagian kewenangan antara Direktorat Jendral Imigrasi dan Direktorat Jendral Pembinaan Pengawasan Ketenagakerjaan, Keselamatan dan Kesehatan Kerja. Kejelasan ini menunjukan bahwa Perpres TKA telah menginternalisasi eksternalitas terhadap potensi risiko dalam perijinan dan pengawasan TKA.

Ketiga, mempromosikan kepentingan publik. Kepentingan publik ada ketika salah satu pihak yang menggunakannya tidak mempengaruhi penggunaan pihak lain, dan pihak pemasok tidak dapat mengeluarkannya. Dalam hal TKA terampil, maka keharusan untuk adanya tenaga kerja pendamping adalah efisien karena TKA terampil tersebut wajib mengikutksertakan tenaga kerja Indonesia sebagai tenaga kerja pendamping. Namun, jika penggunaan TKA low skilled di Indonesia membawa pengaruh kepada sesama tenaga kerja dalam negeri yang berketerampilan rendah, maka kegiatan tersebut tidak efisien karena tidak mempromosikan kepentingan publik. Perpres TKA menurut alasan ini harus mengedepankan kepentingan publik karena salah satu pertimbangan pembentukannya ialah untuk mendukung perekonomian nasional dan perluasan kesempatan kerja melalui peningkatan investasi. Oleh karenanya kepentingan publik akan tetap terjaga jika perluasan kesempatan kerja bagi TKI termuat dalam proses persetujuan penggunaan TKA melalui Rencana Penggunaan Tenaga Kerja Asing (RPTKA). Sudah seharusnya calon pemberi kerja TKA melakukan penyaringan TKI terlebih dahulu yang hasilnya nanti dapat iikutsertakan di dalam RPTKA. Sehingga penggunaan TKA merupakan jalan terakhir bagi pengusaha jika pada akhirnya dan pada kenyataannya TKI tidak bisa menduduki posisi pekerjaan tersebut.

Selain itu, alasan ini menekankan tentang pemisahan secara jelas antara TKA terampil dan belum terampil agar tujuan pengaturan bisa lebih tepat sesuai dengan peruntukannya dan tetap pada kepentingan publik. Kepentingan publik belum terakomodir, walaupun telah ditentukan bahwa TKA baru dapat digunakan jika posisi tersebut tidak dapat diisi oleh TKI, ketidakjelasan basis keterampilan dan keahlian menyebabkan Perpres TKA tidak efisien. Selain itu, oleh karena negara memiliki kekuasaan mutlak untuk membentuk hukumnya melalui pemerintah, maka sesuai dengan Teori Kedaulatan Negara pemerintah berwenang untuk mengatur kembali tentang perizinan penggunaan TKA terampil, bukan TKA secara umum.

Keempat, mendorong alih teknologi dan alih keahlian. Mendorong alih teknologi yang berasal dari TKA terampil dapat menghasilkan eksternalitas positif, baik dalam teknologi produksi untuk perusahaan tersebut dan perusahaan lain, juga mengembangkan kapasitas kemampuan dan keterampilan TKI sebagai tenaga kerja pendamping. Tujuan ini telah ditentukan dalam Pasal 45 ayat (1) Undang-Undang Nomor 13 Tahun 2003 tentang Ketenagakerjaan jo. Pasal 27 Perpres TKA. Menurut penjelasan Pasal 45 ayat (1) Undang-Undang Nomor 13 Tahun 2003 tentang Ketenagakerjaan, tenaga kerja pendamping 
TKA tidak secara otomatis menggantikan atau menduduki jabatan TKA yang didampinginya. Pendampingan tersebut lebih bertujuan pada alih teknologi dan alih keahlian agar tenaga kerja pendamping tersebut dapat memiliki kemampuan tertentu sehingga pada waktunya diharapkan dapat mengganti TKA yang didampinginya. Terdapat sanksi administratif jika Pemberi Kerja TKA tidak melaksanakan alih teknologi dan alih keahlian.

Namun, dalam hal alih tersebut dilakukan namun tujuan alih teknologi dan alih keahlian tidak tercapai maka tujuan alih teknologi dan keahlian selama memperkerjakan TKA sebagaimana dijelaskan dalam Pasal 45 ayat (1) Undang-Undang Nomor 13 Tahun 2003 tentang Ketenagakerjaan tidak terpenuhi. Oleh karenanya Perpres TKA perlu mendorong sekaligus memastikan keberhasilan tujuan proses alih teknologi dan alih keahlian tersebut. Artinya, perlu ditentukan sanksi administratif dalam hal terjadi kegagalan tujuan alih teknologi dan alih keahlian. Dengan demikian tidak tertutup kemungkinan jika proses alih teknologi dan alih keahlian ini gagal dan pengusaha akan tetap menggunakan TKA secara berkelanjutkan karena belum dapat diisi oleh TKI. Perpres TKA juga menjadi tidak efisien jika selama masa hubungan kerja ternyata alih teknologi dan alih keahlian kepada TKA saja yang berhasil dilakukan. Walaupun terdapat kewajiban melaksanakan program penggantian TKA kepada TKI, tidak hanya pengawasan yang diperlukan tetapi menentukan dan menetapkan cara-cara tertentu sehingga hasil akhir dari proses alih teknologi dan alih keahlian ini pada akhirnya dapat berjalan dengan baik. Oleh karena itu sangat perlu adanya cara penyaringan caloncalon yang capable dan profesional sehingga proses alih teknologi dan alih keahlian tersebut benar-benar dapat dijalankan (applicable).

Penyaringan calon TKI harus dilakukan bersama-sama, artinya tidak lagi dilakukan salah satu pihak seperti berdasarkan persyaratan perusahaan atau melalui seleksi yang diselenggarakan oleh Disnaker Kabupaten/ Kota setempat atau bersama-sama dengan instansi teknis lain. Perlu juga didukung dengan kepastian kelancaran komunikasi melalui kemampuan berbahasa. Karena menurut alasan ini, proses alih teknologi dan alih keahlian wajib terlaksanakan secara bertimbal balik, dari dan antara TKA dan TKI, sehingga Perpres TKA harus mampu memastikan keberhasilan proses alih teknologi dan alih keahlian. Melihat pengaturan proses ini Perpres TKA mendelegasikan kembali kepada Menteri, sementara menurut prinsip delegatus non potes delegare, seharusnya Perpres TKA tidak lagi mendelegasikan pengaturan tersebut kepada Menteri karena sudah mendapatkan delegasi dari UndangUndang Republik Indonesia Nomor 13 Tahun 2013 tentang Tenaga Kerja.

Kelima, informasi asimetris. Informasi asimetris terjadi ketika salah satu pihak, pengusaha atau pekerja memiliki informasi banyak atau lebih baik dibandingkan pihak lainnya. Secara umum, ini lebih mengarah kepada pihak produsen, dalam hal ini pengusaha, tentang kebutuhan penggunaan TKA terampil maupun belum terampil dibanding pihak pekerja, meskipun mungkin saja terjadi keadaan sebaliknya. Keberadaan peraturan seharusnya dapat membantu memastikan bahwa TKI memiliki akses ke tingkat informasi yang lebih optimal tentang kebutuhan penggunaan TKA oleh pengguna TKA baik yang terampil maupun yang belum terampil. Hal ini dapat dialkukan dengan membuat persyaratan untuk 
membuka informasi kebutuhan penggunaan TKA sehingga dapat memberikan kejelasan tentang kebutuhan TKA, termasuk keterampilan dan keahlian tertentu serta tanggungjawab para pihak. Dengan adanya kewajiban membuka informasi tersebut dapat dipastikan ketersediaan informasi kepada publik tentang kebutuhan TKA. Dengan demikian jika pada akhirnya tidak dapat diisi oleh TKI, keberadaan TKA untuk mendapatkan pekerjaan di Indonesia menjadi efisien.

Sementara Perpres TKA mewajibkan Pemberi Kerja TKA harus memiliki RPTKA dengan cara mengajukan permohonan kepada Meteri atau pejabat yang ditunjuk untuk mendapatkan pengesahan sebagaimana ditentukan dalam Pasal 7 Perpres TKA, tanpa terlebih dahulu menyebarluaskan kebutuhan penggunaan tenaga kerja kepada TKI. Kepastian informasi asimetris ini jika dilakukan maka penggunaan TKA dapat dilakukan hanya dalam keadaan pekerjaan tersebut benar-benar tidak ada dapat diisi atau dilakukan lagi oleh TKI sehingga pengusaha baru dapat menjadi Pemberi Kerja TKA jika ini menjadi pilihan terakhir.

Selain alasan ekonomi yang dijadikan dasar dalam melakukan pengujian terhadap Perpres TKA, diketahui juga alasan hukum (alasan nonekonomi) yang menjadi pertimbangan, antara lain: Pertama, Mencapai keadilan distributif. Menurut Aristoteles, keadilan distributif merupakan keadilan yang memberikan kepada masing-masing apa yang menjadi suatu hak pada subjek yang juga menilai dari proporsionalitas ataupun kesebandingan yang berdasarkan jasa, kebutuhan dan juga kecakapan. ${ }^{25}$
Melalui regulasi, pemerintah seharusnya mampu mencapai tujuan ini dengan memastikan hak-hak konstitusional TKI, yakni hak untuk mendapatkan pekerjaan (right to work) dan hak dalam pekerjaan (right at work) sekaligus menetapkan hak minimal TKI untuk mendapatkan pelayanan, misalnya informasi asimetris, yang tidak dapat diakses oleh TKI yang memiliki kekuatan tawar yang rendah. Dengan adanya kewajiban membuka informasi tersebut sekaligus memastikan ketersediaan informasi kepada publik tentang kebutuhan TKA maka jika pada akhirnya tidak dapat diisi oleh TKI keberadaan TKA mendapatkan pekerjaan di Indonesia adalah efisien karena mencerminkan keadilan distributif dari alasan informasi asimetris. Dalam hal proses alih teknologi dan alih keahlian, keadilan distributif akan tercapai jika terdapat cara-cara tertentu yang dapat pula memastikan proses ini dapat berhasil sehingga pada akhirnya posisi awal yang hanya bisa diisi oleh TKA dapat tergantikan dengan TKI. Ketika proses ini tidak berhasil, maka tidak berkeadilan jika posisi pekerjaan tersebut hanya terus menerus hanya bisa diisi oleh TKA.

Kedua, Merefleksikan nilai-nilai komunitas. Menurut ajaran umum, pasar dan harga selalu mencerminkan preferensi pribadi konsumen terhadap barang dan jasa yang tersedia. Meskipun preferensi pribadikonsumen berbedabeda terhadap barang dan jasa tertentu, secara alami mereka akan membentuk komunitasnya sendiri. Dalam hal ketenagakerjaan, perspektif ini memberikan kejelasan bahwa kehadiran TKA menunjukkan bahwa tidak ada permintaan terhadap kebutuhan penggunaan TKI. Jika hal

25 Manuel Knoll, "The Meaning of Distributive Justice for Aristotle's Theory of Constitutions" UC3M Universidad Carlos III de Madrid, No.1 (2016), http://e-revistas.uc3m.es/index.php/FONS/article/download/2529/1705 (diakses 30 Oktober 2018). 
ini terjadi, sementara pasokan TKI setidaknya masih sama besar dengan kebutuhan pengusaha maka menurut alasan ini Perpres TKA masih belum merefleksikan nilai-nilai komunitas TKI. Sebab, baik Undang-Undang Nomor 13 Tahun 2003 tentang Ketenagakerjaan maupun Perpres TKA belum membedakan tenaga kerja baik TKA maupun TKI berdasarkan keterampilan dan keahlian, sehingga dalam hal penempatan TKA yang tidak terampil (unskilled) sekalipun menjadi seolah-olah tidak berbeda dengan TKI yang terampil.

Efisiensi Perpres TKA dapat ditelaah lebih lanjut dengan cara mendudukkan kembali klasifikasi TKA yang sudah terbagi menjadi 2 yaitu terampil (skilled) dan yang belum terampil. Jika keterampilan dan keahlian TKA menjadi salah satu parameter penggunaan TKA, maka memperkerjakan TKA terampil untuk mengisi kekosongan TKI terampil merupakan pertukaran sempurna (trade off).

Pembedaan tenaga kerja berdasarkan keterampilan dan keahlian juga telah ditentukan dalam karakteristik ke-lima AEC, yakni Facilitating Movement of Skilled Labour and Business Visitors melalui salah satu langkah strategis dengan cara mengurangi dokumentasi perizinan, jika tidak terstandarisasi, untuk memfasilitasi pergerakan lintas batas sementara.

Mengingat traktat merupakan salah satu sumber hukum formal di Indonesia, hal mana AEC merupakan traktat maka lebih tepat jika TKA terampillah yang diatur dalam kepres, bukan TKA secara umum. Jika klasifikasi ini tidak dilakukan maka nilai-nilai komunitas TKA terampil dan belum terampil akan terus mendapatkan generalisasi yang mengaburkan hak-hak konstitusional masing-masing komunitas.
Ketiga, mendukung kesejahteraan individu. Regulasi terkadang dapat membatasi kebebasan tenaga kerja dalam pencapaian kesejahteraan individu. Menurut alasan ini, jika terdapat regulasi yang belum mendukung secara luas kesejahteraan individu TKI untuk mendapatkan pekerjaan, maka perlu diperlukan penyesuaian antara kebijakan publik dengan peruntukannya untuk meningkatkan daya saing.

Jika mendasarkan pada pertimbangan dalam pemberlakuan Perpres TKA sebagaimana tercantum dalam Konsideran Menimbang butir a dan b Perpres tersebut yaitu: a) bahwa untuk mendukung perekonomian nasional dan perluasan kesempatan kerja memlalui peningkatan investasi, perlu pengaturan kembali perizinan penggunaan tenaga kerja asing; b) bahwa pengaturan perizinan penggunaan tenaga kerja asing yang diatur dalam Peraturan Presiden Nomor 72 Tahun 2014 tentang Penggunaan Tenaga Kerja Asing Serta Pelaksanaan Pendidikan dan Pelatihan Tenaga Kerja Pendamping, perlu disesuaikan dengan perkembangan kebutuhan untuk peningkatan investasi. Maka pada hakikatnya, penyederhanaan perizinan TKA untuk bekerja di Indonesia adalah untuk kepentingan investasi sekaligus memperluas lapangan pekerjaan. Sementara itu, klasifikasi TKA sudah terbagi menjadi 2 yaitu terampil (skilled) dan yang belum terampil. Dalam hal kemudahan perizinan TKA, AEC hanya diperuntukan untuk TKA terampil sesuai dengan karakteristik kelima AEC, yakni Facilitating Movement of Skilled Labour and Business Visitors melalui salah satu langkah strategis dengan cara mengurangi dokumentasi perizinan, jika tidak terstandarisasi untuk memfasilitasi pergerakan lintas batas sementara. Mengingat traktat merupakan salah satu sumber hukum formal di Indonesia, hal 
mana $A E C$ merupakan traktat maka lebih tepat jika TKA terampilah yang diatur dalam Perpres, bukan TKA secara umum.

Pemisahan secara jelas antara TKA terampil dan belum terampil harus dapat dilakukan agar tujuan pengaturan bisa lebih tepat peruntukaanya. Selain itu, oleh karena negara memiliki kekuasaan mutlak untuk membentuk hukumnya melalui pemerintah, maka pemerintah berwenang untuk mengatur kembali tentang perizinan penggunaan TKA terampil, bukan TKA secara umum.

Dalam hal titik fokus Perpres TKA mengarah kepada penyederhanaan perizinan, maka akan efisien jika judul Perpres tersebut menjadi Penyederhanaan Perizinan TKA Terampil, sekali lagi bukan TKA secara umum. Ketika ini terjadi maka pengaturan inti yang memangkas proses perizinan yang sebelumnya memakan waktu 20 hari sekarang menjadi 6 hari.

Lebih lanjut lagi, Perpres TKA akan menjadi efisien jika penyederhanaan perizinan ini bertujuan untuk mengikuti globalisasi dan liberalisasi tenaga kerja serta daya saing, bukan peningkatan investasi. Jika quad non keikutsertaan TKI diarahkan melalui Perpres ini, maka sifatnya akan menjadi daya saing melalui keunggulan komperatif yang harus diiringi dengan pengaturan tentang peningkatan kualitas (keunggulan kompetitif). Oleh karena itu dalam pertimbangan Perpres TKA harus ditambah peningkatan daya saing dalam hal ini memangkas proses perizinan yang sebelumnya memakan waktu 20 hari sekarang menjadi 6 hari. Jika titik fokus Perpres mengarah kepada penyederhanaan perizinan maka judulnya berubah menjadi penyederhanaan perizinan. Perpres TKA menjadi efisien jika penyederhanaan birokrasi ini diarahkan untuk mendukung daya saing secara komperatif, bukan peningkatan investasi, yang harus diikuti dengan peningkatan kualitas (keunggulan kompetitif). Dengan ditingkatkannya keunggulan ini dalam jangka panjang akan membantu peningkatan kesejahteraan individu, khususnya TKI

\section{Penutup}

Berdasarkan hasil telaahan dengan menggunakan metode EAL dengan mengutarakan alasan-alasan ekonomi dan alasan hukum terhadap Perpres TKA, maka dapat disimpulkan bahwa Perpres TKA masih belum memenuhi kriteria efisiensi terutama dalam hal pengaturannya terkait pembagian klasifikasi KA. Oleh karenanya perlu dikembalikan lagi hakikat efisiensi baik dalam aspek birokrasi maupun ketepatan sasaran penggunaan TKA berdasarkan perbedaan keterampilan dan keahlian. Hasil yang diperoleh melalui telaah EAL dapat diperluas melalui analisis dampak regulasi (Regulatory Impact Analysis) untuk mengukur sekaligus meningkatkan efektivitas dan efisiensi sesuai dengan kebijakan yang ditetapkan di dalamnya, khususnya dalam hal reformasi peraturan perundang-undangan dalam hal ini Perpres TKA.

\section{Daftar Pustaka}

\section{Buku}

Abdurachman, A., Ensiklopedia Ekonomi Keuangan Perdagangan (Jakarta: Paradnya Paramita, 1980).

Affandi, Muchtar, Ilmu-ilmu Kenegaraan: Suatu Studi Perbandingan (Bandung: Lembaga Penerbit Fakultas Sosial Politik Universitas Padjajaran, 1982).

Campbell, L. John, Institutional Change and Globalization (Princton: Princeton University Press, 2004).

Cooter, Robert dan Ulen, Robert, Law and Economics (London: Pearson Addison Wesley, 2008). 
Das, Sanchita Basu, ASEAN Economic Community Scorecard: Performance and Perception (Singapore: ISEAS, 2013).

Garner, A. Bryan, Black's Law Dictionary, $8^{\text {th }}$ edition (USA: Thompson West Group, 2004).

Hufron dan Hadi, Syofyan, IImu Negara Kontemporer; Telaah Teoritis Asal Mula, Tujuan dan Fungsi Negara, Negara Hukum dan Negara Demokrasi (Yogyakarta: Laksbang Grafika, 2016).

ljswara, F., Pengantar Ilmu Politik (Jakarta: Binacipta, 1992).

Levanon, Gad, et all, Help Wanted: What Looming Labor Shortages Mean for Your Business (The Conference Board, Research Report R-160116RR, 2016).

Komadar, Bushan J. Journal: The Raise and Fall of a Major Financial Instrument (University of Westminster, 2007).

Martin, A. Elizabeth, Oxford Dictionay of Law, $5^{\text {th }}$ edition (Oxford: Oxford University Press, 2003).

Maslow, H. Abraham dalam Syamsu Yusuf dan Achmad Juntika, Teori Kepribadian (Bandung: Remaja Rosdakarya, 2011).

Pejovich, Svetozar, Law, Informal Rules and Economic Performance (USA: EE, 2008).

Posner, Richard A., Economic Analysis of Law, Edisi 7 (New York: Aspen Publishers, 2007).

Soehino, Ilmu Negara (Yogyakarta: Liberty, 2013).

The Federation of Thai Industries, ASEAN Affairs Department of Foreign Affairs (Ministry and the International Labour Organisation, 2015).

Waters, Malcom, Globalization (London: Routledge, 2003).

\section{Makalah/Artikel/Prosiding/Hasil Penelitian}

Coase, H. Ronald, "The Problem of Social Cost", The Journal of Law and Economics (1960).

Manuel Knoll, "The Meaning of Distributive Justice for Aristotle's Theory of Constitutions" UC3M Universidad Carlos III de Madrid, No.1 (2016), http://e-revistas.uc3m.es/index.php/FONS/ article/download/2529/1705 (diakses 30 Oktober 2018).

Tambunan, Tulus, Makalah: "Pengusaha KADIN Brebes Di Dalam Era Globalisasi: Tantangan dan Ancaman" (Makalah Diskusi dalam Temu Usaha Kadin Brebes 20 Desember 2004).

\section{Internet}

BINUS University International, "Talking Asean: The Business Series Asean @50: Making The Aec Work For The People", http://international. binus.ac.id/2017/08/29/talking-asean-thebusiness-series-asean-50-making-the-aec-workfor-the-people/, BINUS University International (diakses 25 Mei 2018).

Satrio Widianto, "Tenaga Kerja Asing Dari 5 Negara Masih Dominan" ,http://www.pikiran-rakyat. com/ekonomi/2014/08/17/293351/tenagakerja-asing-dari-5-negara-masih-dominan, Pikiran Rakyat (diakses 25 Mei 2018)

ASEAN, "ASEAN Economic Community", ASEAN, http://asean.org/asean-economic-community/ (diakses 21 Mei 2018).

Michael A. Porter, "The Competitive Advantage of Nations", https://hbr.org/1990/03/thecompetitive-advantage-of-nations, Harvard Business Review (diakses 22 Mei 2018). 